\title{
Association of Polymorphisms Calpastatin Gene with Body Weight of Local Sheep in Jonggol, Indonesia
}

\author{
Sutikno ${ }^{a}, b, \#, *$, M. Yamin $c$, \& C. Sumantric \\ aPostgraduate Major Animal Production and Technology, Faculty of Animal Science, Bogor Agricultural University \\ ${ }^{b}$ Konsentrasi Studi Peternakan, Sekolah Tinggi Ilmu Pertanian Kutai Timur \\ Jln. Soekarno Hatta No. 2 Sangatta, Kutai Timur, Kalimantan Timur 75387, Indonesia \\ 'Department of Animal Production and Technology, Faculty of Animal Science, Bogor Agricultural University \\ \#Jln. Agatis Kampus IPB Darmaga, Bogor 16680, Indonesia \\ (Received 30-08-2010; accepted 28-02-2011)
}

\begin{abstract}
Calpastatin (CAST) gene is located on the fifth chromosome of sheep and plays important roles in formation of muscles and meat tenderness after slaughtering. Association of genetic polymorphism in the CAST gene locus MspI and NcoI with body weight was examined in local sheep from Jonggol Animal Science Teaching and Research Unit (JASTRU), Faculty of Animal Science, Bogor Agricultural University. The genotypes for CAST were determined by the PCR-RLFP method. Blood samples were collected from 264 local sheep belonging to JASTRU located in Singosari Village, Bogor District, West Java Province. Extraction of genomic DNA was based on the phenol chloroform method. CAST locus MspI had three genotypes including in MM, MN and NN with frequencies of $0.75,0.23$, and 0.02 respectively. CAST locus NcoI had two genotypes including in MM and MN with frequencies of 0.92, 0.08 respectively. Chi-square test confirmed Hardy-Weinberg equilibrium for the CAST locus MspI and NcoI. There was no significant effects $(\mathrm{P}>0.05)$ of CAST locus MspI and NcoI genotypes on body weight of local sheep in JASTRU.
\end{abstract}

Key words: CAST locus MspI, CAST locus NcoI, body weight, local sheep

\section{INTRODUCTION}

Marker assisted selection is one of new DNA based methods that improves accuracy and progress of selection in animal programmes. Selection using genetic markers are commonly performed to improve productivity in the livestock industry. In general the most documented gene for meat tenderness is calpastatin gene. Calpastatin (CAST) is a specific inhibitor of calpains, making the CAST gene becomes an excellent candidate for controlling meat traits in livestock.

CAST gene is located on the fifth chromosome of sheep and plays important roles in formation of muscles, degradation and meat tenderness after slaughtering. Associations between variation in CAST and carcass and meat quality traits in cattle have been reported previously (Casas et al., 2006; Schenkel et al., 2006) and in sheep, there was also a genetic variation in the CAST gene (Palmer et al., 2000; Zhou et al., 2007; Sumantri et al., 2008; Gabor et al., 2009).

A high degree of polymorphism at the CAST locus had also been reported in studies with Angus bulls

\footnotetext{
* Corresponding author:

E-mail: sutiknoabdulkadir@gmail.com
}

(Chung et al., 2001), crossbred steer and pigs (Kurly et al., 2003). Chung et al. (2001) and Tahmoorespour (2005) have described that there were three allele systems of polymorphic variants (CAST a, b, and c) analysed by PCR-SSCP in a region of the ovine and cattle CAST. Kurly et al. (2003) observed that pigs with the genotype $\mathrm{DD}$ at locus CAST/MspI and FF at locus CAST/RsaI had less fatty acid, thinner back fat and a lower weight of back fat with skin.

The Jonggol Animal Science Teaching and Research Unit (JASTRU) Faculty of Animal Science-Bogor Agricultural University is a Breeding Farm Station located in Singosari Village, Bogor District, West Java Province. Local sheep in JASTRU were produced from crosses and selection programmes since 1980. Sheep keeping under extensive management in JASTRU can adapt on hot tropical climate and dry environment. Genetic variation of sheep from JASTRU was higher compared to another local sheep such microsatellite DNA variation (Sumantri et al., 2008) and gene Pit1 polymorphism (Sumantri et al., 2009). Body weight of local sheep in JASTRU still varied, increased body weight of local sheep can be done through selection and crossing in a sustainable system. These observations suggest that CAST may be considered as a candidate gene for body weight and lean meat in cattle and sheep. In this study 
we have chosen CAST as a candidate gene for body weight in local sheep because of the evidence in cattle (Chung et al., 2001), pig (Kurly et al., 2003) and sheep (Nassiry et al., 2006) implicating a role for the CAST gene in skeletal muscle (Edyta et al., 2002). The aim of this study was to determine existence of any association of polymorphism at the CAST locus MspI and NcoI with body weight characteristics of the local sheep in the JASTRU.

\section{MATERIALS AND METHODS}

\section{Samples}

Blood samples were collected from 264 local sheep belonging to the JASTRU Breeding Station located in Singosari Village, Bogor District, West Java Province, Indonesia.

\section{Procedure}

DNA extraction. DNA was extracted from $200 \mu \mathrm{l}$ of blood as described by Sambrook et al. (1989) by using proteinase $\mathrm{K}$ digestion. Blood samples previously stored in absolute alcohol were washed with deionized water and vortexed for $5 \mathrm{~min}$, and then centrifuged at $8000 \mathrm{rpm}$ for $5 \mathrm{~min}$. Pellet was added $400 \mu \mathrm{l}$ lysis buffer containing $10 \%$ SDS $40 \mu \mathrm{l}$, proteinase $\mathrm{K} 10 \mu \mathrm{l}$, and 1x STE $350 \mu \mathrm{l}$ incubated at $55^{\circ} \mathrm{C}$ for $2 \mathrm{hr}$. The mixture was added phenol solution 400 ul, CIAA (chloroform: isoamyl alcohol = 24:1) $400 \mu \mathrm{l}$, and $5 \mathrm{M} \mathrm{NaCl} 40 \mu \mathrm{l}$ and then shaken slowly at room temperature for $1 \mathrm{hr}$.

The mixture was centrifuged gently at 12,000 rpm for $5 \mathrm{~min}$. Supernatant was collected in fresh sterilized tubes $1.5 \mathrm{ml}$. The DNA was added with absolute alcohol $800 \mathrm{ul}$ and $5 \mathrm{M} \mathrm{NaCl} 40 \mathrm{ul}$ and then freeze at $-20{ }^{\circ} \mathrm{C}$ overnight. After being stored overnight, it was centrifuged at $12,000 \mathrm{rpm}$ for $5 \mathrm{~min}$, and then the supernatant was discarded. DNA was washed with $70 \%$ ethanol and dried. Finally the DNA was dissolved with elution buffer and then stored at $-20^{\circ} \mathrm{C}$.

PCR condition. Reaction was carried out in a total volume of $25 \mu \mathrm{l}$ which consisted of 50-100 ng of template DNA, 2.5 ul PCR buffer 10x (200 mM (NH4) SO $_{4}, 0.1$ $\mathrm{mM}$ tween 20, $750 \mathrm{mM}$ tris- $\mathrm{HCl}, \mathrm{pH} 8.8), 2.5 \mathrm{mM} \mathrm{MgCl}_{2}$, $200 \mu \mathrm{M}$ dNTPs, and $10 \mathrm{pM}$ of each forward and reverse primers and $1 \mathrm{U}$ of taq DNA polymerase. Thermal conditions started with a primary denaturation at $95{ }^{\circ} \mathrm{C}(5$ min) followed by 35 cycles at $95{ }^{\circ} \mathrm{C}$ (45 sec), $62{ }^{\circ} \mathrm{C}(45$ $\mathrm{sec})$, and $72{ }^{\circ} \mathrm{C}(45 \mathrm{sec})$ and then at $72{ }^{\circ} \mathrm{C}(5 \mathrm{~min})$ for final extension.

Exon $1 C / D$ from domain 1 region including the intron of the ovine CAST gene were amplified to a 622 bp fragment by using primers based on Palmer et al. (1998). Primer sequences were:

Ovine 1C: 5'-TGGGGCCCAATGACGCCATCGATG-3' Ovine 1D: 5'-GGTGGAGCAGCACTTCTGATCACC-3'

PCR products were visualized after electrophoresis on $1.5 \%$ agarose gel stained with ethidium bromide.
RFLP (restriction fragment lenght polymorphisms). The amplified fragment of CAST was digested with MspI for CAST locus MspI and NcoI for CAST locus NcoI. $5 \mu \mathrm{l}$ of PCR product was digest with $0.7 \mu \mathrm{l}$ buffer, $5 \mathrm{U}$ (0.3) of MspI or NcoI and $1 \mu \mathrm{H}_{2} \mathrm{O}$ up to a total volume of $2 \mu \mathrm{l}$ then were incubated at $37^{\circ} \mathrm{C}$ for $12-16 \mathrm{~h}$. The digestion products were electrophoresed on $2 \%$ agarose gel in $0.5 \times$ TBE and visualized by ethidium bromide staining for $40 \mathrm{~min}$ at $100 \mathrm{~V}$.

\section{Statistical Analysis}

Frequencies of genotypes and alleles. The relative frequency of particular allele in a population is called the allele frequency (Nei \& Kumar, 2000). Considering a locus with two allele $A_{1}$ and $A_{2}$, the allele frequency of $\mathrm{A}_{1}$ is calculated by

$$
\mathrm{X}_{1}=\left(2 \mathrm{~N}_{11}+\mathrm{N}_{12}\right) / 2 \mathrm{~N}
$$

Description:

$\mathrm{X}_{1} \quad$ = allele frequency of $\mathrm{A}_{1}$

$\mathrm{N}_{11}$ = number of sample in genotype $\mathrm{A}_{11}$

$N_{12}$ = number of sample in genotype $A_{12}$

$\mathrm{N}$ = total sample of population

The genotype frequencies can be detected by calculating the ratio of specific genotypes in the population, $\mathrm{A}_{11}$ genotype frequency can be calculated by following formula (Nei \& Kumar, 2000).

$$
\mathrm{X}_{11}=\mathrm{N}_{11} \mathbb{N}
$$

Description:

$\mathrm{X}_{11}$ = genotype frequency of $\mathrm{A}_{11}$

$N_{11}=$ number of sample in genotype $A_{11}$

$\mathrm{N}$ = total sample of population.

Hardy-Weinberg equilibrium. Hardy-Weinberg equilibrium was tested by the $X^{2}$ statistic (Nei \& Kumar, 2000; Noor, 2008).

$$
x^{2}=\sum \frac{(O-E)^{2}}{E}
$$

\section{Description:}

$\chi^{2} \quad=$ Hardy-Weinberg equilibrium test

$\mathrm{O}=$ observed number of genotype $\mathrm{A}_{11}$

$\mathrm{E}=$ expected number of genotype $\mathrm{A}_{11}$

Association of CAST genotypes with body weight. Association of CAST gonotypes locus MspI and NcoI with body weight were analyzed with the following statistical model (Mattjik \& Sumertajaya, 2002).

$$
\mathrm{Y}_{\mathrm{ij}}=\mathrm{u}+\alpha_{\mathrm{i}}+€_{\mathrm{ij}}
$$

Description:

$\mathrm{Y}_{\mathrm{ij}} \quad$ = mean value of body weight

$\mathrm{u}^{1 \mathrm{j}} \quad$ general mean

$\alpha_{\mathrm{i}} \quad=$ effect of genotypes CAST gen locus MspI or NcoI (i=MM, MN, and NN)

$€ \quad=$ random error 
Data of body weight were corrected by formula below before being used for statistical analysis.

$$
X_{\text {i corrected }}=\frac{\bar{x} \text { standard }}{\bar{x} \text { observed }} x X_{\text {i observed }}
$$

Description:

$X_{i}$ corrected $=$ value of body weight after being corrected by sex and age

X standard $=$ mean of body weight of standard population

X observed $=$ mean of body weight of observed population

$X_{i}$ observed $=$ value of body weight before being corrected by sex and age

\section{RESULTS AND DISCUSSION}

CAST gene fragment was successfully amplified by using a thermal cycler machine (Bio AB System) with annealing temperature at $62{ }^{\circ} \mathrm{C}$ (Figure 1). The structure of amplified CAST gen was $622 \mathrm{bp}$ including $61 \mathrm{bp}$ of exon 1C, $473 \mathrm{bp}$ in intron 1 and $88 \mathrm{bp}$ in exon 1D (Figure 2) with GenBank accession no AF16006 and AF16007 (Palmer et al., 1998). Annealing temperature used for amplification of this segment was the same with annealing temperature being used by Palmer et al. (1998), Nassiry et al. (2006), and Shahroudi et al. (2006).

\section{Genetic Polymorphism of CAST Gen Locus MspI}

The digestion of $622 \mathrm{bp}$ PCR product for CAST gene with restriction endonucleases $M s p I$ differentiated alleles $\mathrm{M}$ and $\mathrm{N}$. The MspI digestion of the PCR products produced digestion fragments of $336 \mathrm{bp}$ and $286 \mathrm{bp}$ for allele $\mathrm{M}$ but the allele $\mathrm{N}$ was not digested. The size of fragment for allele $\mathrm{N}$ was $622 \mathrm{bp}$ after restriction digestion (Figure 3).

In population of local sheep from JASTRU it was detected three genotypes. The homozygous genotype MM (336 bp, 286 bp) was detected in 197 sheep. The heterozygous genotype $\mathrm{MN}$ (622 bp, $336 \mathrm{bp}, 286 \mathrm{bp}$ ) was detected in 62 sheep. The homozygous genotype NN (622 bp) was detected in 5 sheep.

This result differs with Sumantri et al. (2008) work that detected two genotypes only. There had heterozygous genotype $\mathrm{MN}$ and homozygous genotype NN. A similar result was also obtained by Shahroudi et al. (2006) in Karakul sheep in Iran. It was detected that there were three genotypes MM, MN, and NN. A similar study conducted by Gabor et al. (2009) in local sheep in Slovakia and only found two genotypes MM and MN.

\section{Genetic Polymorphism of CAST Gen Locus NcoI}

The digestion of $622 \mathrm{bp}$ PCR product for CAST gene with restriction endonucleases NcoI differentiated alleles $\mathrm{M}$ and $\mathrm{N}$. The NcoI digestion of the PCR products produced digestion fragments of $374 \mathrm{bp}$ and $248 \mathrm{bp}$ for allele $\mathrm{N}$ but the allele $\mathrm{M}$ was not digested. The size of fragment for allele $\mathrm{M}$ was $622 \mathrm{bp}$ after restriction digestion (Figure 4).

In population of local sheep in JASTRU there were detected two genotypes only. The homozygous genotype MM (622 bp) was detected in 242 sheep while the

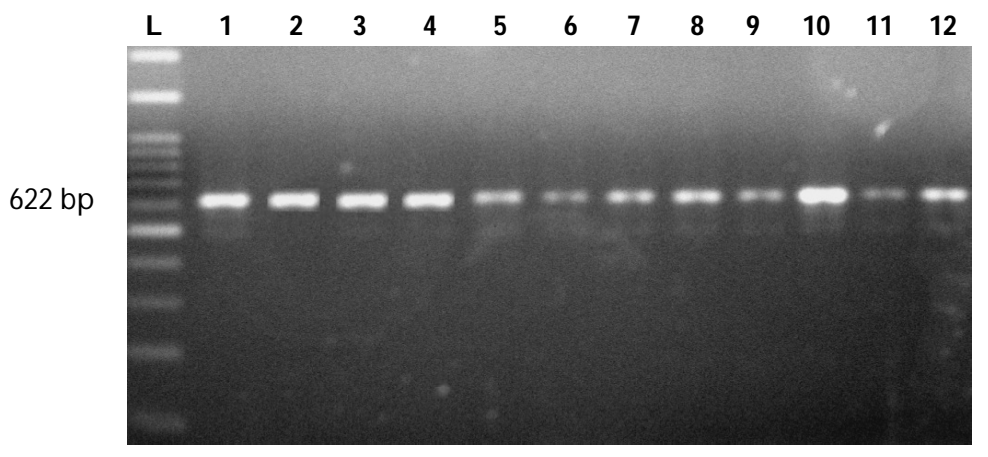

Figure 1. PCR product of CAST gen analyzed by electrophoresis (622 bp). L= ladder $100 \mathrm{bp}$ (Fermentas), and 1-12= PCR product of CAST gen.

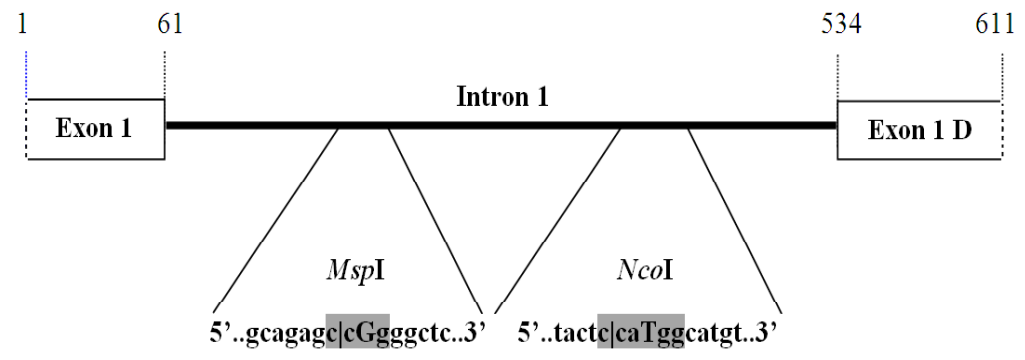

Figure 2. Position of mutation of CAST gene MspI and NcoI loci. Restriction site of enzymes MspI and NcoI (dark shading), point of mutations (bold capital letters and dark shading). 


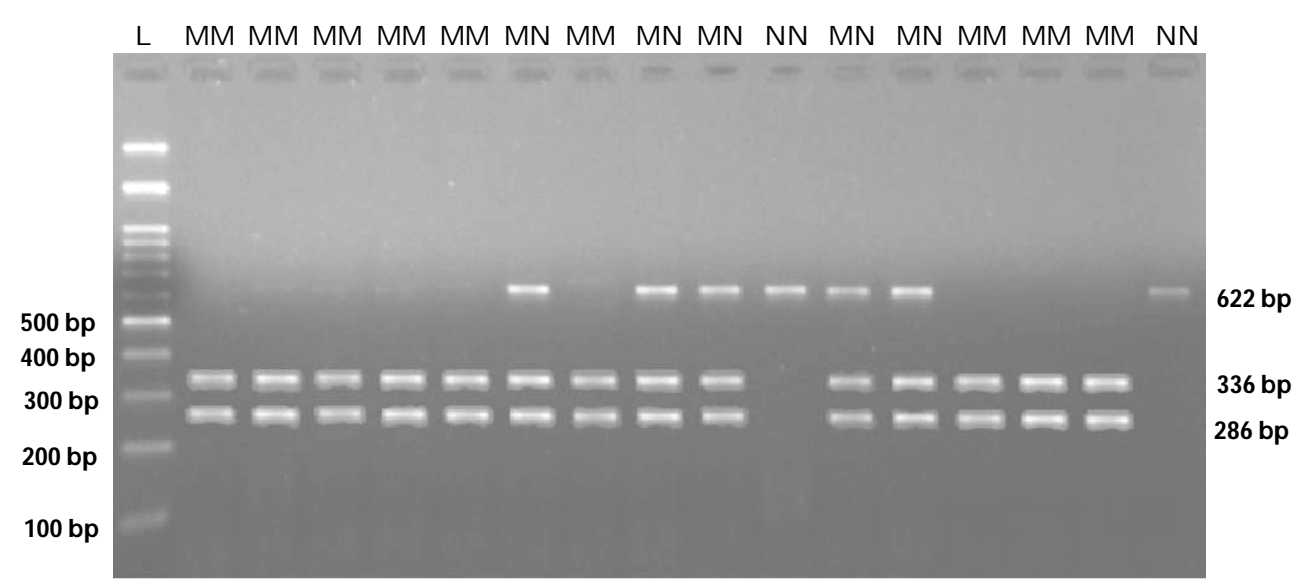

Figure 3. Representatively results of analysis PCR-RFLP for CAST gene by restriction enzyme MspI on $2 \%$ agarose gel. L= ladder 100 bp (Fermentas), MM genotype (336 bp, 287 bp), MN genotype (622 bp, 336 bp, 287 bp), NN genotype (622 bp).

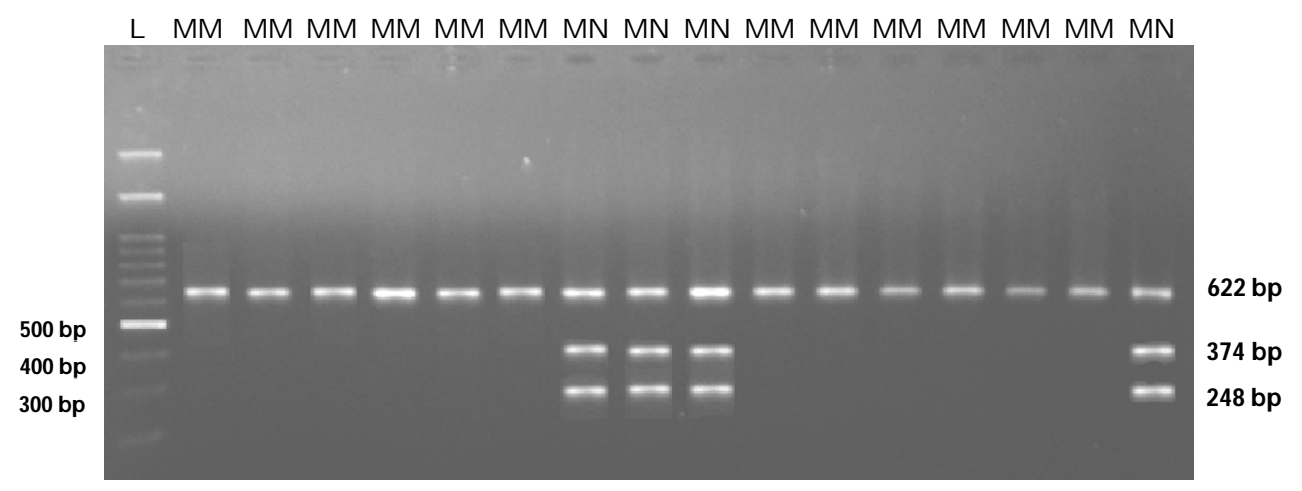

Figure 4. Representatively results of analysis PCR-RFLP for CAST gene by restriction enzyme NcoI on $2 \%$ agarose gel. L= ladder 100 bp (Fermentas), MM genotype (622 bp), MN genotype (622 bp, 374 bp, 248 bp).

heterozygous genotype MN (622 bp, $374 \mathrm{bp}, 248 \mathrm{bp}$ ) was detected in 22 sheep. The homozygous genotype NN (374 bp, $248 \mathrm{bp}$ ) was not determined in the population. This result differed with Palmer et al. (1998) who finding that there were detected three genotypes MM, MN and NN in Dorset Down, Dorset Down $\times$ Coopworth, and Corriedale sheep.

\section{Frequencies of Genotypes and Alleles}

The frequencies of the CAST genotypes, alleles and $\chi^{2}$ test are shown in Table 1 . From the total population of local sheep in JASTRU in CAST locus MspI, it was determined that the frequency of homozygous genotype MM was 0.75; heterozygous genotype MN had frequency of 0.23 , while homozygous genotype NN had frequency of 0.02 . This suggests that a superiority of $\mathrm{M}$ allele 0.86 then $\mathrm{N}$ allele 0.14 in population 264 local sheep could be kept in JASTRU. In the total population of local sheep in JASTRU of CAST locus NcoI was determined that the frequency of homozygous genotype MM had 0.92, while heterozygous genotype MN had frequency of 0.08 . This suggests a superiority of $\mathrm{M}$ allele 0.96 then $\mathrm{N}$ allele 0.04 in population 264 local sheep could be kept in JASTRU.

Polymorphism of CAST gen has also been reported in a variety of other sheep in the world such as the

Table 1. Observed allele and genotypic frequencies and $\chi^{2}$ test for CAST locus MspI and NcoI

\begin{tabular}{|c|c|c|c|c|c|c|c|}
\hline \multirow{2}{*}{ CAST } & \multirow{2}{*}{$\mathrm{n}$} & \multicolumn{2}{|c|}{ Alleles } & \multicolumn{3}{|c|}{ Genotypes } & \multirow{2}{*}{$\chi^{2}$} \\
\hline & & $\mathrm{M}$ & $\mathrm{N}$ & $\mathrm{MM}$ & $\mathrm{MN}$ & $\mathrm{NN}$ & \\
\hline Locus MspI & 264 & 0.86 & 0.14 & 0.75 & 0.23 & 0.02 & $0.060^{\mathrm{ns}}$ \\
\hline Locus NcoI & 264 & 0.96 & 0.04 & 0.92 & 0.08 & 0.00 & $0.576^{\mathrm{ns}}$ \\
\hline
\end{tabular}

$\mathrm{n}=$ total of sample; $\chi^{2}{ }_{0.051}=3.84 ; \mathrm{ns}=$ non-significant; $\mathrm{MM}=$ homozygous genotype $(336 \mathrm{bp}, 287 \mathrm{bp}) ; \mathrm{MN}=$ heterozygous genotype $(622 \mathrm{bp}, 336 \mathrm{bp}, 287$ $\mathrm{bp}$ ); $\mathrm{NN}=$ homozygous genotype (622 bp). 
Table 2. Average of body weight local sheep in The Jonggol Animal Science Teaching and Research Unit (JASTRU), Faculty of Animal Science-Bogor Agricultural University, by CAST genotype locus MspI and NcoI (kg)

\begin{tabular}{lcccc}
\hline \multirow{2}{*}{ CAST } & $\mathrm{N}$ & \multicolumn{3}{c}{ Genotypes } \\
\cline { 3 - 5 } & & $\mathrm{MM}$ & $\mathrm{MN}$ & $\mathrm{NN}$ \\
\hline Lokus $M s p \mathrm{I}$ & 264 & $15.46 \pm 2.65$ & $15.03 \pm 2.09$ & $14.90 \pm 3.28$ \\
& & $\mathrm{~N}=197$ & $\mathrm{~N}=5$ & 0 \\
Lokus NcoI & 264 & $15.36 \pm 2.58$ & $15.24 \pm 2.0$ & $\mathrm{~N}=0$ \\
& & $\mathrm{~N}=242$ & $\mathrm{~N}=22$ & 0 \\
\hline
\end{tabular}

$\mathrm{N}=$ total of sample; $\mathrm{ns}=$ non-significant $(\mathrm{P}>0.05) ; \mathrm{MM}=$ homozygous genotype (336 bp, $287 \mathrm{bp})$; MN=heterozygous genotype (622 bp, $336 \mathrm{bp}, 287 \mathrm{bp})$; $\mathrm{NN}=$ homozygous genotype $(622 \mathrm{bp})$.

Dorset sheep (Palmer et al., 1998), Kurdi sheep in Iran (Nassiry et al., 2006), Karakul sheep in Iran (Shahroudi et al., 2006), Merino, Corriedale, Romney, Poll Dorset, and crossbred NZ sheep in New Zealand (Zhou et al., 2007), and Tsigai sheep, Valachian sheep, East Friesian sheep, Lacaune sheep, and crossbred sheep Lacaune with Tsigai (Gabor et al., 2009).

There was a tendency of local sheep in JASTRU might have higher frequencies $M$ allele than the $N$ allele (Table 1). This result differs from that reported by Sumantri et al. (2008) who found that the genotype frequency of $\mathrm{MN}$ and $\mathrm{NN}$ was 0.32 and 0.68 respectively of local sheep in JASTRU with 22 samples. Some results of other studies also showed similar high frequency of allele M, and low frequency of allele N. Shahroudi et al. (2006) reported that the results of gene CAST locus MspI in Karakul sheep frequencies $\mathrm{M}$ allele was 0.79 and $\mathrm{N}$ was 0.21. Gabor et al. (2009) also reported that the results of CAST gene locus MspI in Tsigai sheep, Improved Valachian, Lacaune, East Friesian, and Tsigai sheep $\times$ Lacaune sheep had allele frequencies of M 0.94 and $\mathrm{N}$ 0.06 .

Genetic equilibrium of population was evaluated by using $\chi 2$-test. The CAST locus MspI had $\chi 2$ value of 0.06. For CAST locus NcoI the $\chi 2$ was 0.576 . A Large population in Hardy-Weinberg equilibrium is defined, if the frequency of genotype $\left(\mathrm{P}^{2}, 2 \mathrm{pq}, \mathrm{q}^{2}\right)$ and frequencies of allele ( $p$ and $q$ ) are constant from generation to generation, because mating occurs roughly at random in a large population (Vasconcellos et al., 2003; Noor, 2008). Selection is one factor that can alter the balance in the population rapidly (Noor, 2008). Hardy-Weinberg equilibrium can be affected by inbreeding, assortative mating, natural selection and population subdivision (Nei \& Kumar, 2000). Current results show that locus MspI and NcoI of CAST gene of local sheep in JASTRU were in Hardy-Weinberg equilibrium.

\section{Association Analysis CAST Genotypes with Body Weight}

The average of body weight of local sheep in JASTRU at each CAST genotype locus MspI and NcoI was summarized in Table 2. The genotype effect for body weight of local sheep in JASTRU was not significant. The present data did not show any influences of CAST genotypes on the body weight of local sheep in JASTRU.
Similarly, Nassiry et al. (2006) reported it did not show any influence of CAST genotype on sheep at weaning to six months old (GWS), six to nine months (GSN), and nine to yearling (GNY).

The rate and extent of skeletal muscle growth ultimately depends mainly on three factors: rate of muscle protein synthesis, rate of muscle protein degradation, and the number and size of skeletal muscle cells. The calpain activity is required for myoblast fusion and cell proliferation in addition to cell growth (Kurly et al., 2003). The calpain system may also affect the number of skeletal muscle cell (fibres) in domestic animals by altering rate of myoblast proliferation and modulation of myoblast fusion. The calpain system is also important in normal skeletal muscle growth. Increased rate of skeletal muscle growth can result from a decreased rate of muscle protein degradation, and this is associated with a decrease in activity of the calpain system. This could due principally to a large increase in calpastatin activity (Kurly et al., 2003). body weight traits was controlled by many genes (polygenes) and was mostly influenced by environmental factor (Noor, 2008).

CAST is a specific inhibitor of the calciumdependent calpain protease family and plays a regulatory role in muscle growth and wastage and in meat tenderization following slaughter (Edyta et al., 2002). This result did not show any influence to body weight of local sheep in JASTRU but may have influence for meat quality. Associations have been reported between variation in CAST and carcass and meat quality traits in cattle (Casas et al., 2006; Schenkel et al., 2006).

Polymorphisms result could be applied for marker in the selection of local sheep with meat quality in future. Currently the consumers preference tend to focus on both quantity and quality traits of sheep meat. This research is a beginning stage to find candidate genes for selection of quantity and quality traits such as double muscle and meat tenderness.

\section{CONCLUSION}

Gene of CAST locus MspI and NcoI were polymorphic in local sheep from JASTRU. The CAST locus MspI had three genotypes $\mathrm{MM}, \mathrm{MN}$ and $\mathrm{NN}$ with frequencies of $0.75,0.23$, and 0.02 respectively. The gene of CAST locus NcoI had two genotypes MM and MN with frequencies of 0.92 and 0.08 respectively. The genotypes 
of CAST gene locus MspI and NcoI did not significantly affect on body weight of local sheep in JASTRU.

\section{ACKNOWLEDGEMENTS}

This research was supported by Directorate General of Higher Education, Ministry of Education Republic of Indonesia through the Hibah Kompetensi 2009 project with contract no. 219/SP2H/PP/DP2MN/2009. We thank to JASTRU (Jonggol Animal Science Teaching and Research Unit) of Faculty Animal Science, Bogor Agricultural University, and thank to Eryk Andreas for blood samples and for technical assistance.

\section{REFERENCES}

Casas E., S. N. White, T. L. Wheeler, S. D. Shackelford, M. Koohmaraie, D. G. Riley, Jr C.C. Chase, D. D. Johnson, \& T. P. L. Smith. 2006. Effects of calpastatin and $\mu$-calpain meakers in beef cattle on tenderness traits. J. Anim. Sci. 84: 520-525.

Chung H.Y., M. S. Davis, \& H. C. Hines. 2001. Effect of calpain and calpastatin genotypes on growth of Angus Bulls. Ohio State University Extension Research Bulletin: Special Circular. 181-201.

Edyta Z.K., S. J. Rosochacki, \& K. Wicinska. 2002. A note on restriction fragment length polymorphism for $\mathrm{HhaI}$ in the bovine calpain gene. Anim. Sci. Pap. Rep. 20: 181-185.

Gábor M. A., Trakovická, \& M. Miluchová. 2009. Analysis of polymorphism of CAST gene and Clpg gene in sheep by PCR-RFLP method. J. Zoot şi Biotehnol. 42:470-476.

Kurly J., W. Kapelanski, \& M. Pierzchala. 2003. Preliminary observations on the effect of calpastatin gene polymorphism in carcass trait in pigs. Anim. Sci. Pap. Rep. 2: 87-95.

Mattjik A. A. \& M. Sumertajaya. 2002. Perancangan Percobaan dengan Aplikasi SAS dan Minitab. Jilid 1. Edisi ke-1. Institut Pertanian Bogor (IPB)-Press, Bogor.

Nassiry M. R., T. Mojtaba, J. Ali, S. Mahdi, \& F. F. Saheb. 2006. Calpastatin polymorphism and its association with daily gain in Kurdi sheep. J. Iran. Biotechnol. 4: 188-192.
Nei, M. \& S. Kumar. 2000. Molecular Evolution and Phylogenetics. Oxford Univ Pr, New York.

Noor, R. R. 2008. Genetika Ternak. Edisi ke-4. Penebar Swadaya, Jakarta.

Palmer B. R., H. Y. Su, N. Roberts, J. G. Hickford, \& R. Bickerstaffe. 2000. Single nucleotide polymorphisms in an intron of the ovine calpastatin gene. Anim. Biotechnol. 11: $63-67$

Palmer B. R., N. Robert, J. G. H. Hickford, \& G. Bickerstaffe. 1998. Rapid comunication: PCR-RFLP for MspI and NcoI in the ovine calpastatin gene. J. Anim. Sci. 76: 1499-1500.

Sambrook, J., E. F. Fritsch, \& T. Maniatis. 1989. Molecular Cloning: a Laboratory Manual. CSH Lab Pr, United State of America.

Schenkel, F. S., S. P. Miller, Z. Jiang, I. B. Mandell, X. Ye, H. Li, \& J. W. Wilton. 2006. Association of a single nucleotide polymorphism in the calpastatin gene with carcass and meat quality traits of beef cattle. J. Anim. Sci. 84: 291-299.

Shahroudi, F. E., M. R. Nassiry, R. Valizadh, A. H. Moussavi, M. T. Pour, \& H. Ghiasi. 2006. Genetic polymorphism at MTNR1A, CAST and CAPN loci in Iranian Karakul sheep. J. Iran. Biotechnol. 4:117-122.

Sumantri, C., R. Diyono, A. Farajallah, \& I. Inounu. 2008. Polimorfisme gen calpastatin (CAST-MspI) dan pengaruhnya terhadap bobot hidup domba lokal. JITV 13:117-126.

Sumantri, C., A. Farajallah, U. Fauzi, \& J. F. Salamena. 2008. Keragaman genetic DNA mikrosatelit dan hubungannya dengan performa bobot badan pada domba local. Med. Pet. 31:1-13.

Sumantri, C. D. Herdiana, A. Farajallah \& D. Rahmat. 2009. Keragaman gen Pituitary-Specific Transcription Factor-1 lokus Pit-1-Hinf1 dan pengaruhnya terhadap bobot tubuh induk, dan produksi susu pada domba lokal. JITV. 14: 222-229.

Vasconcellos, L. P. M. K., D. T. Talhari, A. P. Pereira, L. L. Coutinho, \& L. C. A. Regitano. 2003. Genetic characterization of Arberdeen Angus cattle using molecular markers. J. Genet. Mol. Biol. 26:133-137.

Zhou, H., J. G. H. Hickford, \& H. Gong. 2007. Short communication: Polymorphism of the ovine calpastatin gene. J. Mol. Cell. Prob. 21: 242-244. 